\title{
Świat w powiększeniu. Dziewiętnastowieczny mikroskop jako instrument i jako metafora (na przykładzie twórczości Bolesława Prusa)
}

\author{
Agnieszka BĄBel \\ (Instytut Badań Literackich PAN)
}

W znanym tekście krytycznym, oceniającym metody kreowania świata i postaci przez Prusa-powieściopisarza, Aleksander Świętochowski używa znamiennego porównania:

\Jak wszyscy krótkowidze posiada wzrok wyborny i chwytający najdrobniejsze odcienie z bliska; ale rozległych widnokręgów i znacznych wyniosłości objąć nie może. Toteż wobec wielkich charakterów podobny on jest do malarza, który by dla odtworzenia skały nakreślit ją w obrazach częściowych tak, jak ją oglądał kawałkami pod mikroskopem ${ }^{\mathrm{I}}$.

Urażony tym, co odebrał jako złośliwą krytykę, o ile nie wręcz przytyk osobisty $^{2}$, Prus zaripostował Stówkiem o krytyce pozytywnej, w którym również pojawił się ten sam przyrząd optyczny. Wspominając w części I swoje lata w gimnazjum

1 A. Świętochowski, Aleksander Gtowacki (Bolestaw Prus), w: T. Sobieraj, Prus versus Świętochowski. W sporze o naukowość, krytykę pozytywnq i „Lalkę”, Poznań 2008, s. 88.

2 Gwałtowna reakcja pisarza staje się tym bardziej zrozumiała, gdy uświadomić sobie, jak często owo chwytliwe porównanie Świętochowskiego i jego trop interpretacyjny, łączący wadę wzroku ze sposobem kreowania świata przedstawionego i temperamentem twórczym, będą później powtarzane w najrozmaitszych tekstach krytycznych i wspomnieniowych, nawet przez ludzi bardzo Prusowi życzliwych. Zestawiając Prusa i Sienkiewicza, Adam Breza pisze np.: „Sienkiewicz malował na bardzo dużym płótnie, jaskrawe obrazy, rozpięte na ogromnych sztalugach. Prus skłaniał się raczej ku genialnej miniaturze - co najlepiej znać w jego niezrównanych nowelkach. W miniaturze tej umiał jednak zmieścić szeroki pomysł i z drobnych na pozór rysów złożyć duży wizerunek. Ale p a tr ze nie przez szkło powiększające, badanie drobnoustrojów [wyróżn. A. B.], leżało przede wszystkim w jego temperamencie, charakterze, usposobieniu i w naturze pisarskiej" (idem, Wspomnienia o Bolestawie Prusie, „Ruch Literacki” 1934, nr 10, s. 312). 
lubelskim i charakteryzując panującą wśród niepospolitych uczniów „pozytywną” atmosferę fascynacji nauką, pisarz wśród przykładów na „nadmiar sił, na który chorowała ówczesna młodzież", znajdujący wyraz w szybkim i łatwym przyswajaniu wiedzy oraz zainteresowaniach, wybiegających daleko poza ramy szkolnego programu, przytoczył dokonany przez jednego z rówieśników niezwykły wynalazek. „Najweselszy i najdowcipniejszy z tej gromady śp. Michał S. ${ }^{3}[\ldots]$ miał genialne pomysły mechaniczne: zbudował np. mikroskop, w którym soczewkę przedmiotową zastępowała kropla wody"4.

Świętochowski używa mikroskopu jako metafory specyficznego sposobu postrzegania świata - scjentystycznego, ,zdroworozsądkowego”, a zarazem komicznego w swej drobiazgowości, rozkładającego obraz na atomy i niezdolnego do syntezy w postaci „wielkiej idei”. Prus odwołuje się do konkretu - anegdotycznej wzmianki o oryginalnej koncepcji technicznej, która świadczy zarazem o niezwykłym typie umysłowości i klimacie, w jakim wyrosła. Uczeń gimnazjalny konstruuje bowiem samodzielnie coś, co można by nazwać prostą formą obiektywu immersyjnego (wynalezionego w 1827 r. przez Włocha Giovanniego Amici). Wprowadzenie warstewki płynu między szkiełkiem, przykrywającym preparat, a pierwszą soczewką mikroskopu, pozwala na zmianę współczynnika załamania światła, a co za tym idzie, na wyeliminowanie pewnych zniekształceń obrazu5. Co więcej, ma to zaskakujący wymiar nie tylko techniczny, ale i filozoficzny - przedmiot badania (kropla wody, oglądana pod mikroskopem) staje się elementem narzędzia analitycznego. Dokonuje się zatem swoiste harmonijne (choć chwilowe) scalenie świata, który jest dostępny postrzeganiu podmiotu.

Obaj autorzy wykorzystują odwołanie do tego samego instrumentu optycznego, ale czynią to w sposób diametralnie różny. Można zatem sądzić, że mikroskop był pod koniec XIX wieku narzędziem szczególnym, funkcjonującym jako rozpoznawalny znak kulturowy i językowy: kosztownym elementem wyposażenia gabinetu

3 „Według informacji Zygmunta Szweykowskiego (Przypisy [do:] B. Prus, Studia artystyczne, literackie i polemiki, [w:] idem, Pisma, pod red. Z. Szweykowskiego, t. XXIX, Warszawa 1950, s. 284), jest to Michał Świątkowski. Świątkowski, żyjący w latach 1848-1883, był jednym z najbliższych kolegów Prusa w lubelskim liceum. Odznaczał się zdolnościami plastycznymi, tworząc ilustracje i winietki do redagowanego przez Głowackiego pisemka uczniowskiego «Kurier Łobuzówi». Po zdaniu matury w roku 1866 rozpoczął studia na Wydziale Lekarskim Szkoły Głównej, a po jej zamknięciu - studiował medycynę na Uniwersytecie Warszawskim. W czasie studiów publikował na łamach «Gazety Lekarskiej», zamieszczając w niej rysunki «przedmiotów anatomopatologicznych i chirurgicznych» (zob. J. Goldszmit, Z dziedziny lekarskiej, «Kurier Lubelski» 1869, nr 66). Ukończywszy studia, pracował jako lekarz w Chełmie. Był członkiem Lubelskiego Towarzystwa Lekarskiego". (Przypis Tomasza Sobieraja do: B. Prus, Stówko o krytyce pozytywnej (Poemat realistyczny w 6 pieśniach), w: idem, Prus versus Świętochowski, s. 101). [Dane biograficzne o Michale Świątkowskim pochodzą od prof. Stanisława Fity].

4 B. Prus, Stówwko o krytyce pozytywnej (Poemat realistyczny w 6 pieśniach), w: ibidem, s. 101.

5 http://portalwiedzy.onet.pl/58423,,,,imersyjny_obiektyw,haslo.html (stan z dn. 26 maja 2014 r.). 
naukowca, symbolem badań przyrodoznawczych, a zarazem przedmiotem na tyle dostępnym i powszechnym, by mógł się już zleksykalizować w oczywistych, powszechnie zrozumiałych porównaniach i powiedzeniach.

Mikroskop, którego budowę i zasadę działania warto tu pokrótce przypomnieć, nie jest oczywiście wynalazkiem dziewiętnastowiecznym, choć ta epoka stała się okresem jego doskonalenia i specjalizacji. Nie wdając się w opisy konstrukcji współczesnych mikroskopów, posłużmy się definicją zaczerpniętą z Encyklopedii powszechnej Orgelbranda (I864 r.):

\Mikroskopem nazywa się każde narzędzie optyczne, za pośrednictwem którego patrząc na bardzo drobne przedmioty, widzimy takowe w powiększeniu. Mikroskopy dzielą na pojedyncze i złożone. Mikroskop pojedynczy zwykle lupq (ob.) nazywany, składa się albo z jednej soczewki szklanej, lub z kilku soczewek miejsce jednej zastępujących. Umieszczając przedmiot obserwowany pomiędzy soczewką i jej ogniskiem głównym i patrząc na tenże przedmiot przez soczewkę, otrzymujemy obraz jego rzeczywisty prosty i powiększony. Soczewka jest oprawiona, a jej oprawa połączona z podporą pionową, po której można ją podwyższać i obniżać. Pod soczewką znajduje się stoliczek do układania przedmiotów, a pod nim zwierciadło wklęsłe odbijające promienie światła, padające $\mathrm{z}$ atmosfery i przesyłające je na przedmiot dany. Mikroskop ztożony, zwykle mikroskopem zwany, składa się przynajmniej z dwóch, w pewnej odległości od siebie umieszczonych soczewek szklanych, oprawionych w rurce zwykle mosiężnej; jedna z soczewek zwie się przedmiotową, druga zaś oczną (okularem); przy użyciu mikroskopu pierwsza zwraca się ku przedmiotowi obserwowanemu, przy drugiej zaś umieszcza się oko patrzącego. [...] Obraz powiększony utworzony przez szkło przedmiotowe, okazuje się wtedy znowu powiększonym przez szkło oczne. Prawie we wszystkich dobrych mikroskopach pomiędzy szkłem przedmiotowym i ocznym znajduje się jeszcze trzecia soczewka. Dla dostarczenia dostatecznej ilości światła potrzebnego dla znacznych powiększeń, przedmioty kładzione na stosownej podstawce przed szkłem przedmiotowym, [oświetla się - A. B.] za pośrednictwem zwierciadła wklęłłego, lub za pomocą oddzielnej soczewki, które zgromadzają światło rozpierzchłe nieba lub lepiej od białej chmury pochodzące ${ }^{6}$. 
Zestawy odpowiednio dobranych soczewek były używane już przez szlifierzy holenderskich i włoskich pod koniec XVI w. (Hans i Zachariasz Jensenowie, 1590 r.), pierwsze informacje na temat konstrukcji mikroskopu podaje Galileusz, określając ten instrument mianem „odwróconego teleskopu”. Samo słowo „mikroskop” (gr. mikros 'mały'i skopeo 'patrzę') pojawiło się w I625 r. w korespondencji księcia Federigo Cesiego. Do ważniejszych odkryć, dokonanych przy użyciu prymitywnych mikroskopów w drugiej połowie XVII w., należała komórkowa budowa organizmów żywych (którą jako pierwszy dostrzegł angielski uczony Robert Hooke w I665 r. jego mikroskop powiększał zaledwie 40 razy), oraz istnienie „bardzo drobnych żyjątek”, tj. bakterii, zaobserwowanych przez Holendra Antona van Leeuwenhoeka, o czym przyrodnik doniósł Towarzystwu Królewskiemu w Londynie we wrześniu I674 r. Instrument van Leeuwenhoeka dawał powiększenie 270-krotne, choć miał wysokość zaledwie $5 \mathrm{~cm}$ i był właściwie mikroskopem prostym - posiadał tylko jedną, za to dokładnie oszlifowaną soczewkę o bardzo krótkiej ogniskowej. Pod koniec XVIII w. zaczęto używać obiektywów achromatycznych, skonstruowanych przez Johna Dollonda i Josepha von Freunhofera, a na początku XIX w. udoskonalono to narzędzie, wyposażając je we wspomniany już obiektyw immersyjny (Giovanni B. Amici wykorzystał prace teoretyczne w dziedzinie optyki osiemnastowiecznego matematyka i fizyka Leonhardta Eulera, którego tezy pozwoliły na budowę obiektywów wolnych od aberracji sferycznej i chromatycznej) oraz przyrząd oświetlający (wprowadził go w i872 r. Ernst Abbe, którego wynalazek uwzględniał ugięcie światła na preparacie). Na początku XX w. w zwykłym mikroskopie optycznym można było już uzyskiwać powiększenia rzędu 2000 razy i wykonywać zdjęcia mikroskopowe ${ }^{8}$. Był to przyrząd o bardzo szerokim zastosowaniu, używany w chemii, fizyce, metalurgii (badanie struktury metali), biologii i medycynie (zwłaszcza anatomii patologicznej $\left.{ }^{9}\right)$. Jak podsumowywał anonimowy autor hasła w Encyklopedii Powszechnej:

7 R. Sennett, Etyka dobrej roboty, tłum. J. Dzierzgowski, Warszawa 2010, s. 243.

8 Hasło: „Mikroskop”, w: Wielka Encyklopedia Porwszechna PWN, t. 7, Warszawa 1966, oprac. na podst.: A. Filutowicz i A. Kużdowicz, Mikroskopia i mikrofotografia, wyd. 2, Warszawa 1954; M. Piórkowska, A. Natanek, Przydatnośc badań histologicznych w ocenie jakosci surowca futrzarskiego, „Wiadomości Zootechniczne", R. LI (2013), 1: 83-92, http://www.izoo.krakow.pl/czasopisma/wiadzoot/2013/1/ art10_WZ_2013_1.pdf (stan z dn. 26 maja 2014 r.).

9 „Prawdziwy jednak rozwój przeżyła patologia dopiero od połowy XIX wieku. Wprawdzie już w XVII wieku Holender Leeuvenhoek używał nowo odkrytego mikroskopu do studiowania szczegółów ludzkich mięśni, jakich żadem anatom nie mógł rozpoznać gołym okiem, ale dopiero w wieku XIX rozpoczęła się naprawdę epoka mikroskopu, anatomii mikroskopowej, odkrycia komórki jako ostatniej niepodzielnej cząstki ciała ludzkiego, jak też wszystkich struktur organicznych, mikroskopowej histologii - która śledziła najdrobniejsze szczegóły ludzkich tkanek, studiowała je pod mikroskopem w setkach tysięcy cieniutkich jak włos skrawków, barwiąc to, co niewidoczne, specjalnymi barwnikami - a w końcu mikroskopowej patologii." (J. Thorwald, Stulecie detektywórw, thum. K. Bunsch i W. Kragen, Kraków 2009, s. 195). 
\Spostrzeżenia mikroskopowe służą nie tylko do zaspokojenia ciekawości i do rozszerzenia wiadomości w naukach przyrodzonych, lecz mają udział w udokładnieniu wszystkich wiadomości naszych; mikroskop nadto oddaje ważne usługi w przemyśle, handlu a nawet gospodarstwie domowym, gdyż za pomocą niego [sic!] przekonać się często możemy o sfałszowaniach, których chciwość dopuszcza się na rozmaitych przedmiotach ${ }^{\text {Io }}$.

Nie tyle może sam instrument badawczy „trafil pod strzechy”, co jego używanie w fachowych analizach w charakterze bezdyskusyjnego, naukowego argumentu musiało stać się rzeczą powszechną, skoro np. wydany w Poznaniu w I889 r. anonimowy, popularny poradniczek pt. Gospodyni doskonata, czyli przepisy utrzymywania porzadku $w$ domu... $\mathrm{w}$ rozdziale poświęconym praniu bielizny gromi niedbałe gosposie, sięgając do arsenału scjentystycznego, symbolizowanego właśnie przez mikroskop:
\Bielizna, długo w brudach leżąca, jest wybornym gruntem dla mikro- skopijnej roślinności, gołym okiem niedowidzianej, która się rozwija z największą szybkością i przenika na wskroś tkaninę bielizny. Sądzimy stanowczo, iż pani, która by raz jeden jedyny spojrzała przez mikro- skop na brudną bieliznę, która w brudzie długo leżała, nie odkładałaby nigdy już brudnej bielizny do tak zw. wielkiego prania, które w nie- których domach tylko dwa razy do roku uskuteczniają ${ }^{\mathrm{II}}$.

Mikroskop pojawia się oczywiście również na kartach wielkiej literatury, co znakomicie widać na przykładzie twórczości Bolesława Prusa. Zarówno w jego tekstach publicystycznych, felietonowych, jak i stricte literackich motyw tego instrumentu można odczytywać nie tylko jako świadectwo drobiazgowego realizmu opisu, osadzonego w konkretnym „tu i teraz” zafascynowanej wynalazkami epoki, czy też (w sposób bardziej skomplikowany) jako nieistotny szczegól, którego rolą jest tworzenie „złudzenia referencjalnego” i budowanie Barthesowskiego „efektu rzeczywistości”I2 - ale przede wszystkim jako znak pewnej postawy, element

10 Hasło: „Mikroskop”, w: Encyklopedia powszechna, op. cit., t. 18, s. 588.

11 Gospodyni doskonata, czyli przepisy utrzymywania porzadku w domu $i$ zaopatrzenia go we wszystkie przyprawy, zapasy apteczkowe i gospodarskie, tudzież hodowania i utrzymywania krów, cielat, świń, indyków, kur, kaczek, gęsi itd., co do użytkowania owoców i jarzyn, oraz tajemnice gospodarskie wedle sposobórw najlepszych i najtańszych, wypróbowanych przez doświadczone gospodynie, wraz z „Dodatkiem” zawierajacym pranie i prasowanie bielizny, materyi kolorowych, franek itd., Poznań, nakładem i drukiem Fr. Chocieszyńskiego, 1889, s. 133.

12 Efekt ten ma wytwarzać właśnie nieciągłość, pozorna chaotyczność, przypadkowość świadcząca o prawdopodobieństwie przedstawienia. „Barometr Flauberta, drzwiczki Micheleta w końcu mówią 
charakterystyki bohatera czy wreszcie figurę sposobu widzenia świata. U Prusa nie jest to bowiem instrument „niewinny” i pozbawiony dodatkowych znaczeń.

Mikroskop w kronikach tygodniowych pojawia się regularnie, począwszy od felietonów z rubryki „Z ustronia”, drukowanych w „Niwie” w roku i874, aż po teksty z ostatnich lat (Notatki wotyńskie z I909 r.). Bywa używany zarówno w funkcji atrybutu uczonego czy wręcz „nowożytnego bohatera”, przykładu wyjątkowego wynalazku XVII wieku, argumentu naukowego (często powtarzanego przy ocenie jakości wody warszawskiej) lub zabawnego porównania, podkreślającego miniaturowość, znikomość bądź niedostrzegalność rzeczy, człowieka czy problemu. Oto kilka charakterystycznych ilustracji.

Gdy przybliża się sylwetkę uczonego z okazji jego jubileuszu, jak profesora Marcelego Nenckiego, ukazuje się go przy pracy, badającego „rozumie się przez mikroskop, owe najmniejsze cegiełki, owe komórki, z jakich jest zbudowane ciało ludzi, zwierząt i roślin”’3. Całą kronikę pt. Nowożytny bohater felietonista poświęca fizykowi Ernstowi Abbemu, omawiając jego życiorys na podstawie opublikowanej właśnie skromnej broszurki pióra Władysława Lepperta ${ }^{\mathrm{I} 4}$. Godne pochwały są nie tylko wybitne uzdolnienia matematyka i fizyka Abbego, ale i jego harmonijna współpraca z Karlem Zeissem, właścicielem warsztatu optyczno-mechanicznego w Jenie, która zaowocowała stworzeniem fabryki doskonałych mikroskopów ${ }^{15}$, a przy udziale optyka Friedricha Schotta ucieleśniła ideał połączenia twórczego umysłu, naukowego przygotowania i wytrwałej pracy. Sukces zakładów Zeissa przełożył się na dobrobyt pracowników, a także instytucji naukowych i społecznych, którym z inicjatywy Abbego - skromnego uczonego i filantropa - przekazano prawa właścicielskie: pracownikom fabryki, uniwersytetowi jenajskiemu oraz gminie miasta Jena. „Tak wygląda bohater naszych czasów: dał cywilizacji użyteczne wynalazki, utworzył nowe ognisko pracy, podsycał naukę, przysporzył dobrobytu i oświaty wielu tysiącom istot ludzkich, nikogo nie skrzywdził, siebie umiał usunąć na drugi plan" ${ }^{16}$ - konkluduje Prus.

tylko: jesteśm y r ze czywiste. [...] Innymi słowy, prawdziwym znaczącym realizmu, na korzyść samego przedmiotu odniesienia, jest nieobecność znaczonego". (R. Barthes, Efekt rzeczywistości, tłum. M.P. Markowski, „Teksty Drugie” 2012, nr 4, s. 125 - wyróżn. autora).

13 „Kurier Codzienny” nr 45, dn. 14 lutego 1897, w: Kroniki, t. 15, s. 43. Wszystkie cytaty z kronik tygodniowych za wydaniem: B. Prus, Kroniki, red. Z. Szweykowski, t. 1-20, Warszawa 1953-1970.

14 „Goniec Poranny” nr 18, dn. 6 maja 1904, w: Kroniki, t. 18, s. 90.

15 „Rozwój fabryki opierał się przede wszystkim na geniuszu Abbego, na jego optycznych wynalazkach. Prócz nowych mikroskopów obmyślił on nowe aparaty i obiektywy fotograficzne, refraktometr, spektrometr, aparat do liczenia ciałek krwi, przyrządy do rysowania przedmiotów widzianych przez mikroskopy, celowniki do broni palnej, przyrząd do mierzenia odległości, lornety pryzmatyczne i tak dalej" (ibidem, s. 92, 93).

Ibidem, s. 96-97. 
Mniej imponujące i podniosłe, za to dotyczące żywotnych interesów przeciętnego czytelnika Kronik tygodniowych były liczne wzmianki o złowrogiej zawartości warszawskich wodociągów, której prawdziwą naturę odsłaniał dopiero instrument naukowy. Do ciekawszych inicjatyw, mających unaocznić (i to dosłownie!) wagę problemu należy ta $\mathrm{z}$ lata $1874 \mathrm{r}$.:
》Może przed tygodniem do redakcji „Kuriera Warszawskiego” przy- niósł p. Pik [chodzi o Jakuba Pika, optyka warszawskiego - A. B.] mikroskop powiększający około 500 razy, a z nim kroplę wody wo- dociągowej, w której cała redakcja i ludzie postronni (po wrzuceniu do puszki co łaska) mogli widzieć wielką liczbę wymoczków wcale nie ponętnej powierzchowności. Mikroskop ten wraz z kroplą (mówił dobry „Kurier”) jest do obejrzenia w każdym czasie i (mówimy to już od siebie) gdyby pod nim zmieniano częściej owę kroplę bez zmiany wszakże widoku, w bardzo prosty sposób wyjaśniłby przyczynę straszliwej śmiertelności w Warszawie $[\ldots]^{17}$.

Szacowny przyrząd optyczny bywa też przywoływany w felietonach w celach czysto humorystycznych. Oto na straszliwej pustyni „krzaku ciernia nie dojrzałbyś nawet przez mikroskop"18; urażone w dumie narodowej Polki, którym zarzucono, że to Francuzki są posiadaczkami najdrobniejszych stópek w Europie, rozpoczęły wiosną I89I r. wielką akcję mierzenia, mającą ogłosić światu, „która z przedstawicielek płci pięknej posiada dwudziestocentymetrową nogę, która osiemnastocentymetrową, a która tak małą, że trzeba ją oglądać przez mikroskop?"'19; zaś na rojnej stacji kolejowej w Kowlu, gdzie kronikarz wysiada, by załatwić swoje „mikroskopijne” interesy majątkowe, wprawdzie nie można się przecisnąć między podróżnymi, ale za to "tragarza nie dojrzałbyś przez mikroskop"

Często i chętnie używane przez Prusa zestawianie dwóch kontrastowych przyrządów optycznych: teleskopu i mikroskopu, pełni w tekstach kronik różne funkcje. Niekiedy przy ich pomocy autor podkreśla wszechstronność zainteresowań dziewiętnastowiecznych europejskich badaczy („Więc kiedy jeden uczony śledzi przez teleskop burze na powierzchni słońca, drugi pod mikroskopem przypatruje się życiu istot, których milion pomieściłoby się w łebku szpilki”I) lub odmalowuje

17 „Sprawy bieżące”, „Niwa” t. VI, nr 1, dn. 1 lipca 1874, w: Kroniki, t. 1 cz. 2, s. 14.

18 „Kurier Warszawski” nr 351, dn. 20 grudnia 1885, w: Kroniki, t. 8, s. 248.

19 „Kurier Codzienny” nr 85, dn. 26 marca 1893, w: Kroniki, t. 13, s. 296.

20 „Tygodnik Ilustrowany”, nr 49, dn. 3 grudnia 1909, w: Kroniki, t. 20, s. 296.

21 „Kurier Warszawski” nr 358 b, dn. 29 grudnia 1886, w: Kroniki, t. 9, s. 308. 
wizję idealnych ekspozycji muzealnych (skromność przestrzeni wystawowej zdaje się skazywać na klęskę zbyt ogólnie zakreślone plany Muzeum Przemysłu i Rolnictwa w I876 r. - bo „co mi to za wystawa wyrobów metalowych, na której nie znajdzie się wszystko, począwszy od najcieńszej igły do lokomotywy, od mikroskopu do armaty?...”22), a czasem unaocznia zaskakujące i cenne zdolności krytyka literackiego (o autorze odczytów, Duńczyku Georgu Brandesie: „Posiada on dziwny umysł, który nie tylko jak mikroskop umie wydobywać szczegóły bardzo drobne, ale zarazem działa jak teleskop, który ogarnia widoki dalekie i rozległe" ${ }^{23}$ ). Ta charakterystyczna para, niekiedy określana jako „mikroskop i luneta”, będąca zestawieniem urządzeń przeciwstawnych, a zarazem komplementarnych ${ }^{24}$, powtórzy się w sposób nieoczywisty, bardziej jako sugestia sposobu postrzegania rzeczywistości „miniaturowej” i „kosmicznej”, w króciutkiej nowelce-paraboli Pleśn świata. Najpierw porosty na kamieniu przy Świątyni Sybilli w Puławach zostaną porównane do społeczeństw ludzkich, a następnie cała planeta, widziana $z$ oddali, do pokrytego barwnymi plamkami kamienia. Skala mikro i makro ukazuje niepokojąco podobny obraz mechanicznego rozmnażania, kolonizacji przestrzeni i walki, w którym nie sposób dostrzec przejawów nauki, sztuki, świadomości czy uczuć25. Porosty powrócą jeszcze w Emancypantkach, ze swoim „wyschniętym, trupim życiem” - wyraźną alegorią pustki i samotności, otaczających młodą Adę Solską.

W Lalce mikroskop zdaje się należeć do niezbędnych atrybutów klasy uczonych. Dziwaka doktora Szumana po raz pierwszy widzimy we wspomnieniu Wokulskiego

22 Kroniki miesięczne, „Ateneum”, t. IV, z. 11 - listopad 1876, w: Kroniki, t. 2, s. 573.

23 „Kurier Warszawski” nr 73, dn. 14 marca 1886, w: Kroniki, t. 9, s. 84.

24 Warto zauważyć, że ten trop artystyczny może mieć swoje źródło w samych dziejach owych wynalazków - mikroskop i teleskop w XVI i XVII w. były instrumentami bardzo blisko spokrewnionymi, wykonywanymi przez tych samych rzemieślników, używanymi przez tych samych ludzi - przyrodników, zafrapowanych badaniami natury w rozmaitej skali, a z uwagi na niedoskonałość konstrukcji soczewek również narzędziami wymuszającymi podobne metody rekompensowania wad urządzeń obserwacyjnych. Dla astronomów taką metodę stanowiły obliczenia matematyczne, dla biologów - precyzyjne rysunki, wykonywane przez artystów (np. słynny rysunek oka muchy, zamieszczony w Micrographii Roberta Hooke’a z 1665 r., którego autorstwo przypisywane jest architektowi Christopherowi Wrenowi, zawiera szczegóły niemożliwe do dostrzeżenia za pomocą ówczesnego instrumentu). Zob. R. Sennett, op. cit., s. 249-250.

25 Pleśn świata, w: Pisma Bolestawa Prusa (Aleksandra Gtowackiego), wydanie jubileuszowe, Warszawa 1897, t. 3, s. 270-271. To spojrzenie, narzucane narratorowi przez tajemniczego botanika, jest wizja, którą można uznać za demoniczną, szatańską (ostatnie zdanie brzmi wszak: „Towarzysz mój znik1, alem poznał go już po szyderstwie i melancholii."). Barbara Bobrowska w artykule Kod tradycji-jezyk miejsc (Putawy i Światynia Sybilli w „Pleśni świata”) wspomina tradycję postrzegania drugiej sekwencji Pleśn i świata jako „sceny kuszenia”, powołując się na prace badaczy takich jak Stanisław Fita, Jarosław Okulicz-Kozaryn i Aneta Mazur (w: eadem, Mate narracje Prusa, Gdańsk 2004, s. 309), lecz sama odczytuje nowelę Prusa w sposób bardziej optymistyczny. Uczonego i tajemniczego nieznajomego uznaje bowiem za dwie odrębne postaci, a „szyderczą igraszkę wysłannika piekieł” upatruje w pokusie interpretowania dramatycznych losów Polski przez pryzmat przyrodniczego determinizmu, czyli nieuprawnionego poszukiwania łatwych analogii między porządkiem historiozoficznym a prawami scjentyzmu (ibidem, s. 48-49). 
o rozmowie z przyjacielem przed jego wyjazdem do Bułgarii. „Gdy Wokulski zadzwonił do mieszkania lekarza, ten właśnie był zajęty gatunkowaniem włosów rozmaitych osobników rasy słowiańskiej, germańskiej i semickiej i przy pomocy mikroskopu mierzył dłuższe i krótsze średnice ich przekrojów” ${ }^{26}$. W czasie owej rozmowy, przerywanej zresztą długimi chwilami milczenia, „Gość palił fajkę, gospodarz kręcił się nad mikroskopem" ${ }^{27}$. Przeciwieństwem ekscentrycznego starego przyrodnika i jego badań, które sprawiają wrażenie nieszkodliwej idée fixe, jest twórczy zapał młodego geniusza. Ochocki co prawda ukończył „wydział przyrodniczy w uniwersytecie i mechaniczny w politechnice", ale zajmuje się przede wszystkim „fizyką, chemią i technologią". Wyliczając swoje dotychczasowe osiągnięcia, rzuca niedbale: „Udało mi się ulepszyć mikroskop, zbudować jakiś nowy stos elektryczny, jakąś tam lampę...”28 a zapalony do swojego marzenia o skonstruowaniu machin latających wymienia pogardliwie jednym tchem rzeczy nieistotne w obliczu wielkiej idei - i czyni to w bardzo znaczacej kolejności:

\section{》Co mnie ciotka z jej radami i prawidłami dobrego tonu!... Co mnie żeniaczka, kobiety, a nawet mikroskopy [wyróżn. A. B.], stosy i lampy elektryczne.... Oszaleję albo... przypnę ludzkości skrzydła... ${ }^{29}$}

Ochocki tworzy instrument naukowy, Szuman go zaledwie używa. Badania Szumana są dla Wokulskiego co najwyżej przejawem dobrodusznie tolerowanej manii przyjaciela - wynalazki Ochockiego będą się w jego rozmyślaniach pojawiać pod hasłem "mikroskop i lampa" czy te $\dot{z}$ "mikroskop, stos i lampa elektryczna” jako dowód nieprzeciętnego talentu i wielkiego przeznaczenia młodzieńca, który ze swymi machinami latającymi może trafić do domu wariatów lub stać się większym od Napoleona i Newtona ${ }^{30}$. Na marginesie - w laboratorium tajemniczego metalurga Geista mikroskopu nie ma, tak jakby kojarzył się on Prusowi wyłącznie z narzędziem służącym do analizy przyrody ożywionej.

Metaforycznie używa się mikroskopu w tej powieści tylko raz, za to w wyjątkowo zjadliwym kontekście. Patrząc w pociągu na zakochanego barona Dalskiego, przyrównywanego do uróżowanej mumii, protagonista powieści puszcza wodze wyobraźni i stara się przedstawić sobie uczucia jego narzeczonej. Idealizując w tym momencie kobiety z „uczciwej rodziny”, stwierdza:

26 B. Prus, Lalka, Warszawa 1982, t. 1, s. 85.

27 Ibidem, t. 1, s. 86.

28 Ibidem, t. 1, s. 185.

29 Ibidem, t. 1, s. 189.

30 Ibidem, t. 1, s. 190-191. 
\Oczywiście coś jej strzeliło do głowy i musi być także zadurzona, jeżeli nie w jego wdziękach, to w stanowisku. Inaczej musiałaby zdradzić się, że gra komedię, a baron musiałby spostrzec to, bo miłość patrzy przez mikroskop ${ }^{3 \mathrm{I}}$.

„Miłość, która patrzy przez mikroskop” w ustach zadurzonego Wokulskiego to w świetle późniejszych obserwacji i przeżyć bohatera sformułowanie niemal autoironiczne. Instrument ten bowiem w tej sytuacji nie udoskonala percepcji, ale ją zniekształca - zamiast wyostrzać spojrzenie zakochanego, przykuwa je do nieznaczącego szczegółu, przesłaniającego prawdziwe proporcje i charakter tak obiektu nieodwzajemnionego uczucia, jak i samej relacji międzyludzkiej. Spojrzenie „przez mikroskop" można tu więc (paradoksalnie) interpretować nie jako obiektywne, chłodne poznanie naukowca, lecz jako odbiór rzeczywistości zafałszowany przez nadzieje i emocje patrzącego.

W drugiej wielkiej współczesnej powieści Prusa, Emancypantkach, również pojawia się mikroskop, jest on jednak, można by rzec, przedmiotem tyleż znaczącym, co ściśle wyspecjalizowanym w charakteryzowaniu bohatera, a właściwie bohaterki. Właścicielką tego instrumentu jest bowiem bogata i przejawiająca ambicje naukowe w dziedzinie botaniki Ada Solska. W czasie swojego pobytu na pensji pani Latter młoda milionerka zajmuje dwa pokoje, z których jeden jest skromnie urządzoną, niemal pensjonarską sypialnią, a drugi ma charakter pracowni naukowej ze zbiorami książek, tablicą oraz wielką szafą, kryjącą zestaw przyrządów do badań chemicznych i fizycznych:

\Są tam dokładne wagi, kosztowny mikroskop, zwierciadło wklęsłe, kilkucalowa soczewka, machina elektryczna i cewka Rumkorfa. Nie brak też retort, słoików i flaszek z odczynnikami, jest globus astronomiczny, szkielet jakiegoś ptaka tudzież niezbędny krokodyl, na szczęście bardzo młody i już wypchany.

Wszystkie te przedmioty budzące podziw w uczennicach młodszych, a kłopot w starszych, którym nie zawsze udawało się określić różnicę między mikroskopem i elektroskopem, wszystkie te przedmioty były osobistą własnością panny Solskiej. Ona nie tylko je kupowała i utrzymywała w porządku, ale nawet umiała się z nimi obchodzić [wyróżn. A. B.]. Były to jej balowe suknie, jak mawiała, uśmiechając się łagodnie i smutnie ${ }^{32}$.

31 Ibidem, t. 2, s. 67.

32 B. Prus, Emancypantki, Warszawa 1998, t. 1-2, s. 48. 
To ostatnie zdanie wyraźnie nadaje instrumentom badawczym specyficzny sens, zmieniając je $\mathrm{z}$ „rzeczy samej w sobie” $\mathrm{w}$ przedmioty obciążone dodatkowym znaczeniem i czyniąc z nich punkt wyjścia dla rozbudowanego i subtelnego obrazu „świata na opak”. Młoda emancypantka, która „umie się obchodzić" ze skomplikowanymi przyrządami i nazywa je „balowymi sukniami” (czyli przedmiotem pragnień typowego podlotka), buduje swoje życie na fundamentach odmiennych od tradycyjnych „przeznaczeń kobiety”, jakimi od wieków miały być małżeństwo i macierzyństwo. Badania przyrodnicze stanowią tu odpowiednik zalotów i związku małżeńskiego (by przywołać utarty zwrot o uczonym „poślubionym pracy”), zaś starannie pielęgnowane preparaty zdają się zastępować potomstwo. Pannie Solskiej brak jednak geniuszu Ochockiego, nauka nie jest jej prawdziwym powołaniem, a jedynie mizerną "nagrodą pocieszenia”. Uznawany często za powieściowe porte-parole autora profesor Dębicki naturalne i najwyższe powołanie kobiety widzi w byciu matką, a konstrukcja fabuły i postaci rozmaitych „emancypantek” zdaje się tę opinię w całej rozciągłości potwierdzać.

Samotna Ada, pełna kompleksów z powodu własnej nieatrakcyjnej powierzchowności i nieśmiałości, to bohaterka głęboko nieszczęśliwa. Poczucia spełnienia nie zapewniają jej sukcesy na polu naukowym (chociaż nie ukończyła jeszcze dwudziestu lat, jest wszak chwaloną autorką rozprawy o rozmnażaniu się grzybów). „Kosztowny mikroskop” w rzeczywistości stanowi jedynie zabawkę, rekompensatę braku uczucia, którego jest spragniona, i normalnego życia rodzinnego. Co więcej, rozmowa młodej „sawantki” z Madzią Brzeską, która odbywa się w oranżerii w pałacu Solskich, przerobionej pod kątem botanicznych studiów Ady, wyraźnie pokazuje, że jej fascynacja mchami i porostami, które Madzi wydają się szpetne, suche i zdegenerowane, jest po prostu formą wyładowania niezaspokojonego instynktu macierzyńskiego. Wstając w nocy do swoich preparatów, by zmierzyć poziom oliwy w ogrzewających je lampach czy sprawdzić odpowiednie rozmieszczenia próbek pod kloszami z barwnego szkła, panna Solska traktuje przedmioty swoich badań niczym substytuty dzieci. Sama się zresztą do tego przyznaje, zwierzając się przyjaciółce:

\-[...] Bo otóż pewnego dnia na badanym poroście ukazuje się nowa kropka, listeczek albo guziczek. [...] Powiadam ci, każdy taki nowy utwór wydaje mi się czymś bliskim: cieszę się, gdy rośnie, lękam się, gdy spostrzegę objawy nienormalne, a gdybyś wiedziała, jak mi żal, gdy biedaczek umiera... Zdaje mi się, że jest to małe dziecko, które ja stworzyłam i nie umiem go utrzymać przy życiu ${ }^{33}$. 
Nic dziwnego więc, że Stefan Solski, brat bohaterki i wychowanek Dębickiego, przy całej swej szczerej miłości do siostry wygłasza deprecjonujące komentarze na temat jej pracy badawczej (sprowadzającej się w sumie do tego, że dwudziestoletnia dziewczyna „zdobywa zeza przy mikroskopie w oranżerii, która w tej chwili przypomina piec ognisty..." ${ }^{34}$ ), a ambicje naukowe emancypantek podsumowuje:

1) Patrzyłem na dobre i bogate, które zamiast oddać serce i majątek opłakiwanej prze siebie cierpiącej ludzkości, marnują pieniądze na doświadczenia naukowe, którymi uczony nie połata słomianki do butów... ${ }^{35}$

Ten smutny literacki portret „panny z mikroskopem” można jednak uznać raczej za odzwierciedlenie autorskiego światopoglądu na kwestie emancypacji, niż realnych losów i charakterów kobiet, pod koniec XIX w. na ziemiach polskich dążących do zdobycia wykształcenia. Warto tu przywołać postać prawdziwej emancypantki, jednej z trzech pierwszych studentek na Uniwersytecie Jagiellońskim w latach 1894-1898, która zdobyła tytuł magistra farmacji. Jadwiga Sikorska (zamężna Klemensiewiczowa) okazała się godną spadkobierczynią niezwykłego ucznia lubelskiego gimnazjum, autora "genialnych pomysłów mechanicznych”. Od wczesnej młodości zafascynowana naukami przyrodniczymi, konsekwentnie starała się o zdobycie wyższego wykształcenia. W Warszawie korzystała z możliwości oferowanych przez tzw. Uniwersytet Latający, gdzie na wykładach chemicznych i botanicznych, prowadzonych przez Maksymiliana Heilperna, zapoznała się z techniką przygotowywania preparatów i obsługiwania urządzenia. Jak pisała w swoich wspomnieniach:

1) W ciągu roku szkolnego udało mi się pożyczyć od kogoś znajomego mikroskop na czas dłuższy i wtedy zaczęło się dla mnie istne szaleństwo mikroskopowe. Sprzymierzone tym samym zapałem z Manią Dydyńską, przerabiałyśmy zawzięcie ćwiczenia mikroskopowe z tkanek roślinnych według poleconej nam do tego doskonałej książki dra Henryka Strassburgera i każdą wolną chwilę poświęcałyśmy temu zajęciu $^{36}$.

34 Ibidem, t. 3-4, s. 309.

35 Ibidem, t. 3-4, s. 310.

36 J. z Sikorskich Klemensiewiczowa, Przebojem ku wiedzy. Wspomnienia jednej z pierwszych studentek krakowskich z XIX wieku, Wrocław-Warszawa-Kraków 1961, s. 149. 
W czasie zdobywania murów krakowskiej Alma Mater nie wszyscy członkowie grona profesorskiego byli dla pierwszych studentek (początkowo jedynie hospitantek) życzliwi, ale rzadkie umiejętności, przyswojone sobie w czasie warszawskiej nauki i okresu „szaleństwa mikroskopowego” nieoczekiwanie zaprocentowały, zdobywając dziewczętom nie tylko uznanie i prawo korzystania z wykładów (np. zoologii profesora Wierzejskiego, początkowo niechętnego wyższemu wykształceniu kobiet), ale nawet ciepłe miejsce w pamięci akademików. Sikorska ze szczególnym wzruszeniem i przyjemnością wspominała ćwiczenia z farmakognozji, odbywane pod kierunkiem profesora Łazarskiego:

\Szereg mikroskopów ustawionych na stołach pod oknami, odpowiednie przy nich odczynniki dla zmiękczania i rozjaśniania preparatów robionych z zasuszonych ziół leczniczych; patrzenie jednym okiem w okular mikroskopu, a drugim równocześnie na papier, na którym rysowało się oglądane przez szkło powiększające obrazy - to wszystko było nam tak dobrze znane, tak przypominało nasze warszawskie studia, pierwsze „zapały botaniczne”, pracownię na Wilczej itd. Profesor dziwił się nieraz, skąd umiemy obchodzić się z mikroskopem i odczynnikami, rysowaniem widzianego itd., czego mozolnie musiał uczyć innych swych uczniów. $Z$ dumą opowiadało mu się wtedy o Uniwersytecie Latającym, o którym naturalnie jako Galicjanin nic nie wiedział. Ale umiał ocenić wartość tamtej nauki, bo nie tylko na świadectwie z odbytego kolokwium dopisał własnoręcznie coś o mikroskopowaniu, ale i zapamiętał to sobie przez czas dłuższy. Bo oto w parę lat później, gdy już byłam zamężna, mąż mój opowiedział mi ze śmiechem taką historyjkę: prof. Łazarski, biegnąc szybko drobnym kroczkiem według swego zwyczaju, spotkał na ulicy mego męża; zatrzymał się przy nim, chwycił go za guzik od marynarki i powiedział: „To pan jesteś mężem panny Sikorskiej? Ach panie, jak ona mikroskopowała! Do widzenia panu!" - I pobiegł w swoją stronę 37 .

Jak widać z tego bardzo krótkiego przeglądu, mikroskop, przez który widać „świat w powiększeniu”, jest niezwykle ważnym dla XIX wieku narzędziem postrzegania, tak w dosłownym, jak i metaforycznym sensie. W soczewce instrumentu, utrwalonego w rozmaitych tekstach (literackich, wspomnieniowych, publicystycznych), można dojrzeć obraz epoki, charaktery jednostek i społeczeństw, a w jego okularze - oko patrzącego. 


\section{Bibliografia:}

Bobrowska B., Kod tradycji - jezzyk miejsc (Putawy i Światynia Sybilli w Pleśni świata), w: eadem, Mate narracje Prusa, Gdańsk 2004;

Encyklopedia powszechna, t. 18, Nakład, druk i własność S. Orgelbranda, Księgarza i typografa, Warszawa 1864, s. 586 (reprint WAiF, Warszawa 1985);

Gospodyni doskonata, czyli przepisy utrzymywania porzadku w domu i zaopatrzenia go we wszystkie przyprawy, zapasy apteczkowe i gospodarskie, tudzież hodowania i utrzymywania krów, cielat, świń, indyków, kur, kaczek, gęsi itd., co do użytkowania owoców i jarzyn, oraz tajemnice gospodarskie wedle sposobów najlepszych i najtańszych, wypróbowanych przez doświadczone gospodynie, wraz z „Dodatkiem” zawierajacym pranie i prasowanie bielizny, materyi kolorowych, franek itd., Poznań, nakładem i drukiem Fr. Chocieszyńskiego, 1889;

Klemensiewiczowa z Sikorskich J., Przebojem ku wiedzy. Wspomnienia jednej z pierwszych studentek krakowskich z XIX wieku, Wrocław-Warszawa-Kraków 1961;

Prus B.:

Emancypantki, Warszawa 1998, t. 1-4;

Kroniki, red. Z. Szweykowski, t. 1-20, Warszawa 1953-1970;

Lalka, Warszawa 1982, t. 1-2;

Pleśn świata, w: Pisma Bolestawa Prusa (Aleksandra Gtowackiego), wydanie jubileuszowe, Warszawa 1897 , t. 3, s. 270-271;

R. Sennett, Etyka dobrej roboty, ttum. J. Dzierzgowski, Warszawa 2010;

Sobieraj T., Prus versus Świętochowski. W sporze o naukowośc, krytykę pozytywnq i „Lalkę”, Poznań 2008;

Thorwald J., Stulecie detektywórw, tlum. K. Bunsch i W. Kragen, Kraków 2009;

Wielka Encyklopedia Porwszechna PWN, t. 7, Warszawa 1966.

Piórkowska M., Natanek A., Przydatnośc badań histologicznych w ocenie jakości surowca futrzarskiego, „Wiadomości Zootechniczne”, R. LI (2013), http://www.izoo.krakow.pl/czasopisma/wiadzoot/2013/1/ art10_WZ_2013_1.pdf;

http://portalwiedzy.onet.pl/58423,,,,imersyjny_obiektyw,haslo.html.

SŁOwA KLUCzE: mikroskop, historia wynalazków, Bolesław Prus, metafora

Agnieszka Bąbel

The World Under Magnification. The Nineteenth-Century Microscope as a Tool and as a Metaphor (Based on the Works of Boleslaw Prus)

The text is devoted to the invention of the microscope and its image in the literature of the nineteenth century. An outline of the history of this optical tool provides a background for presenting the nineteenth-century microscope as a sign of a certain cognitive attitude, or characteristics of a protagonist, and finally - of the way 
of seeing the world in selected texts by Boleslaw Prus (Stówko o krytyce pozytywnej ['A Word on Positivist Criticism'], Kroniki ['Chronicles'], The Fungi of this World, The Doll, The Emancipationists), supplemented with examples derived from the "utility literature" and memoirs (Orgelbrand's Encyklopedia porwszechna ['Popular Encyclopaedia'], household guides or memories of one of the first female students in Krakow - Jadwiga Klemensiewiczowa from Sikorski’s family).

KeY words: microscope, history of inventions, Boleslaw Prus, metaphor 